\title{
Hormonal assessment before and after vasectomy
}

\author{
D C G SKEGG, J D MATHEWS, J GUILLEBAUD, M P VESSEY, S BISWAS, K M FERGUSON, \\ Y KITCHIN, M D MANSFIELD, I F SOMMERVILLE
}

British Medical fournal, 1976, 1, 621-622

\begin{abstract}
Summary
Animal experiments have suggested that vasectomy may disturb the endocrine function of the testis. To explore this possibility in man blood was obtained from 277 men who had undergone vasectomy up to six years earlier or who were about to undergo the operation. Mean plasma testosterone concentrations seemed to be slightly higher in those who had undergone vasectomy than in the preoperative group, although this difference was not statistically significant. There was no significant difference between these two groups in the concentrations of luteinising hormone, follicle-stimulating hormone, prolactin, or oestradiol.
\end{abstract}

\section{Introduction}

During the past decade millions of men have undergone vasectomy, but there have been surprisingly few studies of the physical sequelae of the operation. Recently three groups of workers reported decreased testicular hormone production after vasectomy in rats. ${ }^{1-3}$ These results have emphasised the need for studies of the possible long-term effects in man. We report here the hormonal findings from an epidemiological study of men before and after vasectomy.

\section{Methods}

Five groups of men were selected, comprising 100 about to have a vasectomy and 210 who had already undergone the operation (50 six months earlier, 50 one year earlier, 50 two years earlier, and 60 five years earlier). The pre-vasectomy group was selected from the waiting list and the next three groups from the operation register of the Elliot-Smith Clinic in Oxford. The fifth group was selected from the operation register of the Simon Clinic in Swindon, where vasectomy was first undertaken at an earlier date than in Oxford. Men were identified consecutively by operation date, but towards the end of the study every other man aged under 40 was excluded from the prevasectomy group to increase the proportion of older men in this group.

With the approval of general practitioners men were sent a letter inviting them to attend the clinic. Those who ignored three appointments were interviewed in their homes whenever this was possible.

Department of Regius Professor of Medicine, University of Oxford, Oxford

D C G SKEGG, BMEDSC, MB, Rhodes scholar

J D MATHEWS, MD, FRACP, research fellow

Nuffield Department of Obstetrics and Gynaecology, University of Oxford, Oxford

J GUILLEBAUD, FRCSED, MRCOG, research fellow

Department of Social and Community Medicine, University of Oxford, Oxford

M P VESSEY, MD, FFCM, professor

Department of Biochemical Endocrinology, Chelsea Hospital for Women, London

S BISWAS, MB, PHD, lecturer in physiology

$\mathrm{K} M$ FERGUSON, BSC, senior biologist

Y KITCHIN, MSC, PHD, senior biochemist

M D MANSFIELD, FIMLT, senior technologist

I F SOMMERVILLE, MD, PHD, director
Attempts to see a man were stopped immediately if he objected to the study. Men were generally seen in the early evening. They completed a questionnaire and were interviewed and examined before blood was taken. Plasma was separated quickly, stored at $-20^{\circ} \mathrm{C}$, and sent to the laboratory in batches containing specimens from each group of subjects.

The plasma concentrations of follicle-stimulating hormone (FSH), luteinising hormone $(\mathrm{LH})$, and prolactin were measured by double antibody radioimmunoassay techniques. The radioimmunoassays for testosterone and oestradiol-17 $\beta$ have been described elsewhere. ${ }^{45}$

\section{Results}

Subjects studied-The 100 men in the pre-vasectomy group were all traced and seen. Of the 210 men who had undergone vasectomy, 188 were seen, eight refused to participate, six had emigrated, five were traced but not seen, and three could not be traced. The process of follow-up was sometimes so protracted that the interval between operation and interview was longer than intended. It was therefore necessary to redefine the groups for analysis according to the actual time that had elapsed since vasectomy. Some of the characteristics of the men in these groups and in the pre-vasectomy group are summarised in table $I$. As expected, mean age tended to increase with time since the operation, but the groups were reasonably comparable in height, weight, and age at first intercourse. Men who had undergone vasectomy at least five years earlier tended to have had more children. This presumably reflects a reluctance in the past to perform the operation on men with small families.

TABLE I-Characteristics of the groups

\begin{tabular}{|c|c|c|c|c|c|c|}
\hline \multirow[t]{2}{*}{ Characteristic } & \multirow{2}{*}{$\begin{array}{l}\text { Pre- } \\
\text { vasectomy } \\
\text { group }\end{array}$} & \multicolumn{4}{|c|}{$\begin{array}{c}\text { Post-vasectomy groups } \\
\text { Time since operation (years) }\end{array}$} & \multirow[t]{2}{*}{ Total } \\
\hline & & $<1$ & $1-2$ & $3-4$ & $\geqslant 5$ & \\
\hline $\begin{array}{l}\text { No of patients } . \\
\text { Mean age at interview (years).. } \\
\text { Mean age at first intercourse }\end{array}$ & $\begin{array}{l}100 \\
35.5\end{array}$ & $\begin{array}{l}28 \\
37 \cdot 5\end{array}$ & $\begin{array}{l}66 \\
36.9\end{array}$ & $\begin{array}{l}47 \\
40 \cdot 3\end{array}$ & $\begin{array}{l}47 \\
41 \cdot 5\end{array}$ & 288 \\
\hline $\begin{array}{lll}\text { (years) } & \\
\text { Mean No of children } & . & \ldots \\
\text { Mean height }(\mathrm{cm}) & \ldots & \ldots \\
\text { Mean weight }(\mathrm{kg}) & \ldots & \ldots\end{array}$ & $\begin{array}{r}18.8 \\
2.4 \\
174.8 \\
77.1\end{array}$ & $\begin{array}{r}19 \cdot 0 \\
2 \cdot 7 \\
174 \cdot 2 \\
71 \cdot 1\end{array}$ & $\begin{array}{r}19 \cdot 2 \\
2 \cdot 7 \\
176 \cdot 0 \\
76 \cdot 4\end{array}$ & $\begin{array}{r}19 \cdot 4 \\
2 \cdot 5 \\
172 \cdot 5 \\
78 \cdot 1\end{array}$ & $\begin{array}{r}19 \cdot 1 \\
3 \cdot 2 \\
174 \cdot 8 \\
74 \cdot 9\end{array}$ & $\begin{array}{r}19 \cdot 1 \\
2 \cdot 6 \\
174 \cdot 5 \\
76 \cdot 2\end{array}$ \\
\hline
\end{tabular}

Plasma hormones-Blood specimens were obtained from 277 men. The distributions of hormone values were positively skewed, so logarithmic transformation was carried out before analysis. Geometric means of plasma hormone concentrations, together with the results of analysis of variance, are presented in table II. Mean plasma testosterone was lower in the men before operation than in the postoperative groups, but the difference was not statistically significant. There was no significant heterogeneity among the groups in mean plasma concentrations of LH, FSH, prolactin, or oestradiol.

\section{Discussion}

It will never be possible to conduct randomised controlled trials of vasectomy, so inferences must be drawn from imperfectly controlled observations and animal experiments. Prospective studies of long-term effects in man are desirable, but they will take some years to complete. Despite the limitations of our cross-sectional approach, the results are reassuring. Any major changes should have been evident in a study of this size.

The mean testosterone concentrations in this study were lower than the mean previously reported for normal men using the same method of estimation. ${ }^{4}$ This is probably because blood 
TABLE II-Plasma hormone levels (geometric means) in groups of men before and after vasectomy. Standard errors of mean log ${ }_{10}$ concentrations are given in parentheses.

\begin{tabular}{|c|c|c|c|c|c|c|c|c|c|}
\hline \multirow{2}{*}{ Hormone } & \multirow{2}{*}{$\begin{array}{c}\text { No of } \\
\text { estimations }\end{array}$} & \multirow{2}{*}{$\begin{array}{l}\text { Pre-vasectomy } \\
\text { group }\end{array}$} & \multicolumn{5}{|c|}{$\begin{array}{l}\text { Post-vasectomy groups } \\
\text { Time since operation (years) }\end{array}$} & \multicolumn{2}{|c|}{ Variance ratio* } \\
\hline & & & $<1$ & $1-2$ & $3-4$ & $\geqslant 5$ & All times & $\begin{array}{l}\text { All five } \\
\text { groups }\end{array}$ & $\begin{array}{l}\text { Before vasec- } \\
\text { tomy } v \text { after } \\
\text { vasectomy }\end{array}$ \\
\hline 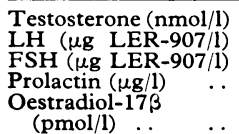 & $\begin{array}{l}277 \\
269 \\
266 \\
258\end{array}$ & $\begin{array}{r}9.1(0.015) \\
57.9(0.020) \\
87 \cdot 1(0.025) \\
12.4(0.033)\end{array}$ & $\begin{array}{r}11.4(0.028) \\
59.0(0.036) \\
83.2(0.038) \\
9.4(0.063)\end{array}$ & $\begin{array}{r}9.8(0.023) \\
56.4(0.024) \\
94 \cdot 0(0.026) \\
12 \cdot 6(0.038)\end{array}$ & $\begin{array}{r}9.9(0.035) \\
57.5(0.035) \\
98.9(0.026) \\
11.4(0.054)\end{array}$ & $\begin{array}{r}9.4(0.031) \\
60.7(0.031) \\
95.3(0.034) \\
15.1(0.048)\end{array}$ & $\begin{array}{l}10.0(0.015) \\
58.2(0.015) \\
93.8(0.015) \\
12.3(0.025)\end{array}$ & $\begin{array}{l}1.73 \\
0.18 \\
0.86 \\
1.84\end{array}$ & $\begin{array}{l}3.06 \\
0.002 \\
1.30 \\
0.005\end{array}$ \\
\hline
\end{tabular}

* To achieve $5 \%$ level of significance variance ratio would have to exceed 2.40 for comparison of five groups and 3.87 for comparison of two groups.

Conversion: SI to traditional units-Testosterone: 1 nmol $/ 1 \approx 28 \cdot 8 \mathrm{ng} / 100 \mathrm{ml}$. Oestradiol-17 $\beta$ : $1 \mathrm{pmol} / 1 \approx 0 \cdot 272 \mathrm{pg} / \mathrm{ml}$.

specimens were taken in the evening, when testosterone concentrations are generally lower than during the day. ${ }^{6}$ ?

Previous studies of testicular endocrine function at one month ${ }^{8}$ and up to three months ${ }^{9}$ after vasectomy have not shown significant changes. Smith $e t \mathrm{al}^{10}$ followed men for up to a year after the operation, but over a quarter of their subjects were either excluded or untraced. They reported a significant increase in both mean plasma testosterone and LH after vasectomy; in our study mean testosterone concentrations (though not $\mathrm{LH}$ levels) were slightly higher in men who had undergone vasectomy.

If testosterone levels really are higher after vasectomy several explanations are possible. Firstly, there may be an increased frequency of intercourse after the operation, and this may affect testosterone secretion. ${ }^{11}$ Secondly, psychological stress may suppress plasma testosterone $;^{12}$ expectation of the forthcoming surgery might therefore lower the preoperative testosterone concentrations. Finally, there may be an actual increase in Leydig cell population after vasectomy. Although the results of animal experiments are not consistent, hyperplasia of Leydig cells after vasectomy has been suggested, ${ }^{13}{ }^{14}$ and Gupta et al ${ }^{15}$ recently reported a similar histological change in some humans.

Clearly the endocrine effects of vasectomy remain uncertain, and, although our results are reassuring, long-term prospective studies are essential.

We thank Professor Sir Richard Doll for his advice; Mr D W G
Budd, Mrs Rotha Peers, and staff of the Elliot-Smith Clinic in Oxford and $\mathrm{Mr} \mathrm{J}$ K Monro and staff of the Simon Clinic in Swindon for their co-operation and help. Mr D Hunter, Dr J I Mann, and other colleagues gave valuable help. We are indebted to $\mathrm{Dr} W \mathrm{R}$ Butt and the National Pituitary Agency (USA) for gifts of antigen and antiserum and to Mrs Diana Collinge and Mrs Gale Mead for secretarial work.

\section{References}

1 Sackler, A M, et al, Science, 1973, 179, 293.

2 Nickell, M D, et al, Federation Proceedings, 1974, 33, 531.

3 Kinson, G A, and Layberry, R A, Contraception, 1975, 11, 143.

4 Collins, W P, et al, fournal of Steroid Biochemistry, 1972, 3, 333.

5 Emment, Y, Collins, W P, and Sommerville, I F, Acta Endocrinologica, $1972,69,567$.

${ }^{6}$ Rowe, P H, et al, fournal of Endocrinology, 1974, 61, 63.

7 Rose, R M, et al, fournal of Endocrinology, 1972, 54, 177

${ }^{8}$ Bunge, R G, Investigative Urology, 1972, 10, 9.

- 9 Johnsonbaugh, R E, et al, Fertility and Sterility, 1975, 26, 329.

10 Smith, K D, Chowdhury, M, and Tcholakian, R K, in Control of Male Fertility, ed J J Sciarra, C Markland, and J J Speidel, p 169. Hagerstown, Harper and Row, 1975.

11 Ismail, A A A, and Harkness, R A, Acta Endocrinologica, 1967, 56, 469.

12 Kreuz, L E, Rose, R M, and Jennings, J R Archives of General Psychiatry, 1972, 26, 479.

13 Easterday, J L, et al, Research Communications in Chemical Pathology and Pharmacology, 1973, 6, 301.

14 Kothari, L K, Mishra, P, and Mishra, R K, American fournal of Surgery, 1973, 126, 84.

15 Gupta, A S, et al, British fournal of Surgery, 1975, 62, 59.

\title{
The retroverted gravid uterus and its effect on the outcome of pregnancy
}

\author{
A R L WEEKES, R D ATLAY, V A BROWN, E C JORDAN，S M MURRAY
}

British Medical fournal, 1976, 1, 622-624

\section{Summary}

Among 1954 pregnant women who booked before the end of the 14th week of gestation the uterus was retroverted in $220(11.2 \%)$. The incidence of bleeding in early pregnancy and spontaneous abortion was significantly higher

\footnotetext{
Department of Obstetrics and Gynaecology, Mill Road Maternity Hospital, Liverpool L6 $2 \mathrm{AH}$

A R L WEEKES, FRCSED, MRCOG, senior registrar

R D ATLAY, MB, MRCOG, consultant

V A BROWN, $\mathrm{MB}, \mathrm{CHB}_{\text {, registrar }}$

New Medical School, University of Liverpool, Liverpool L69 3BX

E C JORDAN, medical student

S M MURRAY, medical student
}

in the retroverted group. Only three patients $(1.4 \%)$ with a retroverted gravid uterus developed acute retention of urine. Patients with retroverted uteri did not have a higher incidence of previous infertility, nor any increase in the incidence of common obstetric abnormalities.

\section{Introduction}

The retroverted gravid uterus is now thought to cause fewer problems than was once believed, and its importance as a contributory factor in infertility and abortion has been the subject of changing opinion..$^{1-3}$ It is no longer thought to be associated with a higher incidence of abortion but this view is largely based on the results of a small series of cases ${ }^{4}$; furthermore, this contention has never been statistically proved. ${ }^{5}$ We sought to clarify whether retroversion of the uterus in early pregnancy was associated with a significantly higher incidence of abortion when compared with pregnancies occurring in women with a normally 